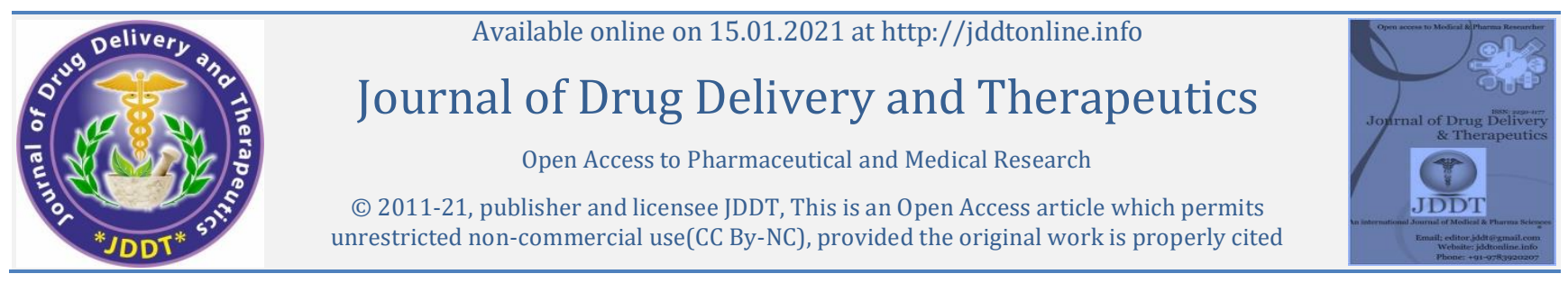

(C) 2011-21, publisher and licensee JDDT, This is an Open Access article which permits Ipen Access Full Text Article

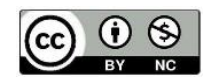

Research Article

\title{
Formulation and In Vitro Evaluation of Bilayer Tablets of Lansoprazole and Amoxycillin Trihydrate for the Treatment of Peptic Ulcer
}

\author{
Neha Singh ${ }^{1 *}$, Durga Pandey ${ }^{1}$, Nilesh Jain ${ }^{2}$ and Surendra Jain ${ }^{1}$ \\ ${ }^{1}$ Sagar Institute of Research \& Technology-Pharmacy, Ayodhya Bypass Road, Bhopal, M.P. India - 462041 \\ ${ }^{2}$ Sagar Institute of Research Technology \& Science-Pharmacy, Near ISRO, Bhopal, M.P. India - 462041
}

\begin{tabular}{l}
\hline Article Info: \\
\hline Article History: \\
Received 12 Nov 2020; \\
Review Completed 21 Dec 2020 \\
Accepted 29 Dec 2020; \\
Available online 15 Jan 2021
\end{tabular}

Cite this article as:

Singh N, Pandey D, Jain N, Jain S, Formulation and In Vitro Evaluation of Bilayer Tablets of Lansoprazole and Amoxycillin Trihydrate for the Treatment of Peptic Ulcer, Journal of Drug Delivery and

Therapeutics. 2021; 11(1):23-31

DOI: http://dx.doi.org/10.22270/jddt.v11i1.4481

*Address for Correspondence:

Nilesh Jain, Professor, Sagar Institute of Research

Technology \& Science-Pharmacy, Ayodhya Bypass

Road, Bhopal - 462041

E-mail: prof.nileshjain@gmail.com
Abstract

The present work involves the formulation development, optimization and In-vitro evaluation of bilayer tablet containing Lansoprazole in the immediate release layer and Amoxycillin in the sustained release layer, using sodium starch glycolate as a super disintegrant for the immediate release layer and the hydrophilic matrix HPMC $\mathrm{K} 100 \mathrm{M}$, hydrophobic matrix Ethyl cellulose are used in the sustained release layer. Bilayer tablet showed as initial burst effect to provide dose of immediate release layer Lansoprazole to control the acid secretion level and the sustained release of Amoxycillin for 24 hours. Immediate and sustained release tablets were formulated by wet granulation method because of the poor flow property of the blends. The prepared bilayer tablet was evaluated for their precompression parameters, physical characteristics like hardness, friability, uniformity of weight, uniformity of drug content, swelling index, In-vitro floating studies and In-vitro drug release. The release of the lansoprazole from the immediate release layer was found to be $97.46 \pm$ $0.15 \%$ in 15 minutes. The release of Amoxycillin Trihydrate for the sustained release floating layer was found to be $98.25 \pm 0.14 \%$ in 12 hours. Lansoprazole potentiate the effect of Amoxycillin. Hence the bilayer tablets of Lansoprazole and Amoxycillin were used to improve patient compliance towards the effective management of ulcer.

Keywords: bilayer tablet, Lansoprazole, and Amoxycillin, sustained release

\section{INTRODUCTION}

Lansoprazole is a proton pump inhibitor (PPI) which inactivates the final step in the gastric acid secretion pathway in gastric parietal cells in a dose-dependent manner. Bioavailability is $85 \%$ after the first dose - the highest among PPIs and acid inhibition is swift, resulting in rapid relief of symptoms. Lansoprazole also exhibits antibacterial activity against Helicobacter pylori in vitro ${ }^{1,} 2$. Lansoprazole is also effective in combination with different regimens for $H$. pylori eradication and is included in the firstline PPI-based options for this purpose 3 .

Amoxicillin is a semi-synthetic aminopenicillin, with a broadspectrum bactericidal activity ${ }^{4-6}$, used as trihydrate in oral products ${ }^{3}$. Amoxicillin trihydrate is likely a white or almost white crystalline powder 7 , and it is well absorbed when given orally, with a bioavailability ( 95 Oral\%) that appears to be much higher than expected based on its physicomechanical and biopharmaceutical properties, and the $\mathrm{pH}$ partition theory ${ }^{8}$. Because of its poor solubility, amoxicillin trihydrate can be considered as a drug-candidate which may give rise to dissolution-related bioavailability problem ${ }^{9}$.

Bi-layer tablet is a unit compressed tablet dosage form intended for oral application. It contains two layers in which one layer having conventional or immediate release part of single or multiple active ingredients, another layer is sustained or controlled release part of single or multiple active ingredients.

Nowadays various developed and developing countries move towards combination therapy for treatment of various diseases and disorders requiring long term therapy such as hypertension, diabetes and cardiovascular diseases. Combination preparation plays an important role in clinical treatment because of its better and wider curative synergism and weaker side effects. Combination therapy may be achieved by giving separate drugs or where available by giving combination drugs (monolithic or bilayer dosage form) which are dosage forms that contain more than one active ingredient.

To provide effective, safe and stable pharmaceutical oral formulation containing anti-ulcer drug Lansoprazole as immediate release layer and oral antibiotic drug Amoxicillin as sustained release layer for effective treatment of peptic ulcer ${ }^{10}$.

Generally, conventional controlled-release dosage forms delay the release of drugs and do not provide a rapid onset of action after oral administration 11 . Hence, the layered tablets offer a pharmacokinetic advantage over conventional controlled- release dosage forms as the drug is quickly released from the fast-release layer leading to rapid rise of 
drug plasma concentration followed by continuation of drug release from the sustained release layer ${ }^{12}$.

\section{MATERIALS AND METHODS}

Lansoprazole and Amoxycillin were received as gift by Sri Pharmacare Powai, Mumbai, India. HPMC K100M, Ethyl cellulose, Sodium starch glycolate, Polyvinyl pyrrolidone $\mathrm{K}$ 30, Magnesium stearate, Talc, Microcrystalline cellulose, Isopropyl alcohol, obtained from S.D. fine chemicals, Mumbai. Sodium bicarbonate, citric acid, magnesium stearate and talc were obtained from Loba Chemical Pvt Ltd (Mumbai, India). All other chemical was purchased from $\mathrm{Hi}$ Media, Mumbai. Double distilled water was prepared freshly and used whenever required. All other chemicals used in this study including those stated were of analytical reagent (A.R.) grade.

\section{Formulation Development}

\section{Formulation of Immediate release granules of Lansoprazole}

To improve the onset of action the immediate granules of lansoprazole were prepared by wet granulation technique. Sodium starch glycolate (SSG) was used as a super disintegrant in $4 \%, 6 \%$ and $8 \%$ concentrations to improve the dissolution of the drug. The granules were compressed by 10 station compression machines. Composition of tablets is mentioned in Table 1 . The immediate release tablet of lansoprazole was formulated and optimized. The optimized formulation was used for the final bilayer tablets.

Table 1 Composition of Immediate Release Granules

\begin{tabular}{|c|c|c|c|c|}
\hline S.NO & Ingredients & $\mathbf{N}-\mathbf{1}(\mathbf{m g})$ & $\mathbf{N}-\mathbf{2}(\mathbf{m g})$ & $\mathbf{N}-\mathbf{3}(\mathbf{m g})$ \\
\hline 1 & Lansoprazole & 15 & 15 & 15 \\
\hline 2 & Sodium starch glycolate & 8 & 12 & 16 \\
\hline 3 & Polyvinyl pyrrolidone K-30 & 8 & 8 & 8 \\
\hline 4 & Magnesium stearate & 4 & 4 & 4 \\
\hline 5 & Talc & 2 & 2 & 2 \\
\hline 6 & Microcrystalline cellulose & 162 & 158 & 154 \\
\hline 7 & Lake ponceau 4R & 1 & 1 & q.s \\
\hline 8 & Isopropyl alcohol & 200 & 200 & 200 \\
\hline
\end{tabular}

\section{Formulation of amoxycillin sustained release tablets}

The sustained release granules were prepared by wet granulation technique. Different polymers such as HPMC K $100 \mathrm{M}$ and Ethyl cellulose were used in different ratios. The tablets were compressed by 10 station compression machine using $\mathrm{mm}$ punches. The optimized batch of sustained release tablets of amoxycillin was then compressed with the optimized batch of immediate release Lansoprazole tablets to get bilayer tablets. Composition of tablets is mentioned in Table 2. The sustained release tablet of amoxycillin was formulated and optimized. The optimized formulation was used for the final bilayer tablets.

Table 2 Composition of Sustained Release Granules

\begin{tabular}{|c|c|c|c|c|c|c|}
\hline S.NO & Ingredients & NA-1(mg) & NA -2(mg) & NA -3(mg) & NA -4(mg) & NA -5(mg) \\
\hline 1 & Amoxycillin & 500 & 500 & 500 & 500 & 500 \\
\hline 2 & HPMC K100 M & - & 50 & 25 & 50 & 75 \\
\hline 3 & Ethyl cellulose & 50 & - & 25 & 25 & 25 \\
\hline 4 & Polyvinyl pyrrolidone & 12.5 & 12.5 & 12.5 & 12.5 & 12.5 \\
\hline 5 & Magnesium stearate & 10 & 10 & 10 & 10 & 10 \\
\hline 6 & Talc & 2.5 & 2.5 & 2.5 & 2.5 & 2.5 \\
\hline 7 & Microcrystalline cellulose & 165 & 165 & 165 & 140 & 115 \\
\hline 8 & Isopropyl alcohol & q.s & q.s & q.s & q.s & q.s \\
\hline & Total weight & 740 & 740 & 740 & 740 & 740 \\
\hline
\end{tabular}

\section{Formulation of bilayer tablet}

Optimized formulation N-3 of Instant release layer (Lansoprazole) and optimized formulation of NA-5 (Amoxycillin) for control release used for formulation of Bi- layer tablet. Optimized immediate layer of Lansoprazole was prepared by wet granulation method. Optimized sustained release layer of Amoxycillin was prepared by wet granulation method. 


\section{Evaluation of Precompression Parameter ${ }^{13}$}

Angle of repose ( $\theta)$

The angle of repose was determined by using fixed funnel method. The physical mixtures of drug with different excipients were prepared and the accurately weighed drug powder or its physical mixture was taken in a funnel. The height of the funnel was adjusted in such a way that the tip of the funnel just touches the apex of the heap of the drug powder. The powder was allowed to flow through the funnel freely onto surface. The angle of repose was calculated using the following equation.

$\boldsymbol{\theta}=\tan -\mathbf{1}(\mathbf{h} / \mathrm{r})$ Where, $\mathrm{h}$ and $\mathrm{r}$ are the height and radius of the powder cone respectively.

\section{Bulk density/tapped density}

Both loose bulk density (LBD) and tapped density (TBD) were determined were calculated using the following formulas.

\section{LBD = Powder weight/volume of the packing \\ TBD = Powder weight $/$ tapped volume of the packing \\ Compressibility index}

The compressibility index of the granules was determined by Carr's compressibility index.

$$
\text { Carr's index }(\%)=[(T B D-L B D) / T B D] \times 100 .
$$

\section{Hausner's ratio}

Hausner's ratio is an indirect index of ease of measuring the powder flow. It was calculated by the following formula7-9.

\section{Hausner's ratio $=$ Tapped density $/$ Bulk density . \\ Evaluation of Post Compression Parameter}

\section{Shape and color of tablets}

Uncoated tablets were examined under a lens for the shape of the tablet and colour was observed by keeping the tablets in light.

\section{Thickness}

Three tablets were picked from each formulation randomly and thickness was measured individually. It is expressed in $\mathrm{mm}$ and standard deviation was also calculated. The tablet thickness was measured using dial-caliper (Mitutoyo, Japan).

\section{Hardness}

For each formulation, the hardness of five tablets was determined using the Monsanto hardness tester and measured in terms of $\mathrm{kg} / \mathrm{cm} 2$.

\section{Weight variation}

Twenty tablets were selected randomly from each formulation and average weight was determined. The tablets were weighed individually and compared with average weight. The U.S Pharmacopoeia allows a little variation in the weight of a tablet.

\section{Friability}

A sample of twenty randomly selected tablets were accurately weighed and placed in a Roche friabilator. The friabilator was operated for $4 \mathrm{~min}$ at a speed of $25 \mathrm{rpm}$. The tablets were removed from the friabilator, de-dusted and reweighed. The percent loss in weight due to abrasion and impact was calculated as,

\%Friability= (Loss in weight/ Initial weight) $\times 100$

\section{Hardness test}

The hardness of tablet was measured by Pfizer hardness tester and results were expressed in $\mathrm{Kg} / \mathrm{cm}^{2}$.

\section{Drug Content Study}

\section{For IR Tablets Containing Lansoprazole}

Twenty tablets were selected randomly, weighed and finely grounded. An accurately weighed quantity of powder equivalent to $10 \mathrm{mg}$ of Lansoprazole was transferred to a $100 \mathrm{ml}$ volumetric flask and dissolved. The volume was made upto the mark with $0.1 \mathrm{M} \mathrm{HCl}$. From this solution $10 \mathrm{ml}$ was taken and further diluted with $0.1 \mathrm{M} \mathrm{HCl}$ in a $100 \mathrm{ml}$ volumetric flask. The absorbance of the resulting solution was measured at $281 \mathrm{~nm}$ taking $0.1 \mathrm{M} \mathrm{HCl}$ as blank using UV-Visible spectrophotometer. The concentration was obtained from the calibration graph.

\section{For SR Tablets Containing Amoxycillin}

Twenty tablets were selected randomly, weighed and finely grounded. An accurately weighed quantity of powder equivalent to $50 \mathrm{mg}$ of Amoxycillin was transferred to a $100 \mathrm{ml}$ volumetric flask and dissolved in $5 \mathrm{ml}$ of $0.1 \mathrm{~N} \mathrm{NaOH}$ and the volume was made upto the mark with $\mathrm{pH} 6.8$ phosphate buffer. From this solution $10 \mathrm{ml}$ was taken and further diluted with $\mathrm{pH} 6.8$ phosphate buffer in a $100 \mathrm{ml}$ volumetric flask. From this solution $5 \mathrm{ml}$ was taken and diluted with pH 6.8 phosphate buffer in $50 \mathrm{ml}$ volumetric flask. The absorbance of the resulting solution was measured at $228 \mathrm{~nm}$ taking $\mathrm{pH} 6.8$ phosphate buffer as blank using UV- Visible spectrophotometer. The concentration was obtained from the calibration graph.

\section{Bilayer Tablets of Lansoprazole and Amoxycillin (Simultaneous Equation Method) ${ }^{14}$}

Simultaneous estimation of Lansoprazole and Amoxycillin was carried out using UV-Visible

The following equations were used to determine the contents.

$$
\begin{gathered}
C x=\frac{A_{2} a_{y} 1-A_{1} a_{y} 2}{a_{x} 2 a_{y} 1-a_{x} a_{y} 2} \\
C y=\frac{A_{1} a_{x} 1-A_{2} a_{x} 1}{a_{x} 2 a_{y} 1-a_{x} a_{y} 2}
\end{gathered}
$$

where, $\mathrm{a}_{\mathrm{x} 1}$ and $\mathrm{a}_{\mathrm{x} 2}=$ The absorptivity of drug $\mathrm{X}$ at $\lambda_{1}$ and $\lambda_{2}$ respectively. ay1and $\mathrm{ay}_{2}=\mathrm{The}$ absorptivity of drug $\mathrm{Y}$ at $\lambda_{1}$ and $\lambda_{2}$ respectively.

$A_{1}$ and $A_{2}=$ The absorbance of sample at $\lambda_{1}$ and $\lambda_{2}$ respectively.

$\left(\mathrm{A}_{1} / \mathrm{A}_{2}\right) /\left(\mathrm{a}_{\mathrm{x} 1} / \mathrm{a}_{\mathrm{x} 2}\right)$ and $\left(\mathrm{a}_{\mathrm{y} 1} / \mathrm{a}_{\mathrm{y} 2}\right) /\left(\mathrm{A}_{1} / \mathrm{A}_{2}\right)$

The ratios should lie outside the range of $0.1-2.0$ for the precise determination of $X$ and $Y$ drugs. This criteria is satisfied only when the $\lambda_{\max }$ of the two components is reasonably dissimilar and the components should not interact chemically.

1. Preparation of standard stock solution of Lansoprazole 9

Lansoprazole equivalent to $100 \mathrm{mg}$ was accurately weighed and dissolved. The volume was made upto mark with $\mathrm{pH}$ 6.8phospahte buffer in $100 \mathrm{ml}$ standard flask. From this solution $10 \mathrm{ml}$ was taken and diluted with $\mathrm{pH} 6.8$ phospahte buffer in $100 \mathrm{ml}$ volumetric flask. From this solution $10 \mathrm{ml}$ 
was taken and further diluted with $\mathrm{pH}$ 6.8phospahte buffer in $100 \mathrm{ml}$ standard flak.

\section{Preparation of standard stock solution of Amoxycillin 47}

Amoxycillin equivalent to $100 \mathrm{mg}$ was accurately weighed and dissolved. The volume was made upto mark with $\mathrm{pH}$ 6.8phospahte buffer in $100 \mathrm{ml}$ standard flask. From this solution $10 \mathrm{ml}$ was taken and diluted with $\mathrm{pH} 6.8$ phospahte buffer in $100 \mathrm{ml}$ volumetric flask. From this solution $10 \mathrm{ml}$ was taken and further diluted with $\mathrm{pH}$ 6.8phospahte buffer in $100 \mathrm{ml}$ standard flak.

\section{Preparation of sample solution}

Twenty tablets were selected randomly, weighed and finely grounded. An accurately weighed quantity of powder equivalent to $100 \mathrm{mg}$ of Amoxycillin was transferred to a $100 \mathrm{ml}$ volumetric flask and dissolved in $5 \mathrm{ml}$ of $0.1 \mathrm{~N} \mathrm{NaOH}$ and the volume was made upto the mark with $\mathrm{pH} 6.8$ phosphate buffer. From this solution $10 \mathrm{ml}$ was taken and further diluted with $\mathrm{pH} 6.8$ phosphate buffer in a $100 \mathrm{ml}$ volumetric flask. From this solution $10 \mathrm{ml}$ was taken and further diluted with $\mathrm{pH} 6.8$ phosphate buffer in a $100 \mathrm{ml}$ volumetric flask. The absorbance of resulting solution was measured at $281 \mathrm{~nm}$ and $228 \mathrm{~nm}$ respectively. The amounts of both the drugs were determined.

\section{In Vitro Disintegration Studies for IR Tablets}

The disintegration time was determined using disintegration test apparatus. The tablets were placed in each of the six tubes of the basket. The assembly was suspended in $0.1 \mathrm{M}$ $\mathrm{HCl}$ maintained at a temperature of $37 \mathrm{C} \pm 2 \mathrm{C}$ and the apparatus was switched on. The time taken to disintegrate the tablets completely was noted.

\section{In Vitro Dissolution Studies ${ }^{15}$}

\section{For IR tablets}

The release of Lansoprazole was determined using Type II (paddle) dissolution apparatus under sink condition. $900 \mathrm{ml}$ of $0.1 \mathrm{M} \mathrm{HCl}$ was used as dissolution medium at a temperature of $37 \mathrm{C} \pm 0.5 \mathrm{C}$. The paddle was stirred at a speed of $50 \mathrm{rpm}$. The release studies were carried out for 30 mins. The absorbance of the solution was measured at $281 \mathrm{~nm}$ taking $0.1 \mathrm{M} \mathrm{HCl}$ as blank using UV-Visible spectrophotometer.

\section{For SR tablets}

The release of Amoxycillin was determined using Type II (paddle) dissolution apparatus under sink condition. $900 \mathrm{ml}$ of $\mathrm{pH} 6.8$ phosphate buffer was used as dissolution medium at a temperature of $37 \mathrm{C} \pm 0.5 \mathrm{C}$. The paddle was stirred at a speed of $50 \mathrm{rpm}$. The release studies were carried out for 24hours. The absorbance of the solution was measured at $228 \mathrm{~nm}$ taking pH 6.8 phosphate buffer as blank using UVVisible spectrophotometer.

\section{For bilayer tablets}

The release of bilayer tablet was determined using Type II (paddle) dissolution apparatus under sink condition. 900ml of $0.1 \mathrm{M} \mathrm{HCl}$ was used as dissolution medium for first two hours followed by $\mathrm{pH} 6.8$ phosphate buffer solution for next eight hours maintained at a temperature of $37 \mathrm{C} \pm 0.5 \mathrm{C}$. The paddle was stirred at a speed of $50 \mathrm{rpm}$. The release studies were carried out for ten hours. The absorbance of the solution was measured at $281 \mathrm{~nm}$ and $228 \mathrm{~nm}$ taking respective buffer solutions as blank using UV-Visible spectrophotometer and the calculations were done by simultaneous equation method.

\section{RESULTS AND DISCUSSION}

The present work was aimed to formulate bilayer tablets of immediate release Lansoprazole and sustained release Amoxycillin. The therapy with these drugs offers a good quality of life for patients who are suffering from gastric ulcer.

\section{Preformulation Studies Drug Characterization Lansoprazole}

Lansoprazole and amoxycillin were tested Description, Loss on drying, Solubility, Melting point as per in house specification and found satisfactory for formulation. The drug source is identified and found complying with the specifications.

\section{Physical compatibility study}

The compatibility studies were carried out to study the possible interactions between active ingredients (Lansoprazole \& Amoxycillin) and inactive ingredients. Physical mixtures of both API and excipients were prepared separately as per the ratios mentioned in table below and kept for stability at $40 \mathrm{C}$ and $75 \% \mathrm{RH}$ for one month. Samples were taken out after every 10 days and were subjected to physical and chemical compatibility tests. The physical compatibility study was performed visually. The study implies that the drug and the excipients were physically compatible with each other as there was no change of physical parameters. The excipients which are compatible with the drug were selected for the formulation.

\section{Chemical compatibility study}

All the samples were scanned at the wave number region of 4000-400 $\mathrm{cm}^{-1}$ using $\mathrm{KBr}$ disc method. This $\mathrm{KBr}$ discs were formed by taking drug and $\mathrm{KBr}$ in a ratio of 1: 100 respectively. Then this mixture was mixed well in mortar for three to five minutes. A very small amount of this mixture was uniformly spread and sandwiched between the pellets and pressed using $\mathrm{KBr}$ pellet press at a pressure of 20,000 psi for $1 \mathrm{~min}$.The pressure was then released and pellet was placed into the pellet holder and thus scanned in the IR region. No shift and no disappearance of characteristic peaks suggesting that there is no interaction between the drugs and also with the excipients in the final formulation.

\section{Drug Content study}

\section{Calibration Curve of Lansoprazole}

Calibration curve of Lansoprazole in $0.1 \mathrm{M} \mathrm{HCl}$ is shown that the solution of Lansoprazole in $0.1 \mathrm{M} \mathrm{HCl}$ show linearity $\left(\mathrm{R}^{2}\right.$ $=0.999)$ at concentrations of $5-25(\mu \mathrm{g} / \mathrm{ml})$ and obey Beer Lambert Law at $\lambda \max 281 \mathrm{~nm}$.

\section{Calibration Curve for Amoxycillin}

Calibration curves of Amoxycillin in $\mathrm{pH} 6.8$ phosphate buffer is shown It was found that the solution of Amoxycillin in $\mathrm{pH}$ 6.8 phosphate buffer show linearity $\left(R^{2}=0.999\right)$ at concentrations of 2-10 $(\mu \mathrm{g} / \mathrm{ml})$ and obey Beer and Lambert Law at $\lambda \max 228 \mathrm{~nm}$.

\section{Precompression Study for IR Formulation}

The API and the formulated blends were evaluated for precompression parameters and results were shown in table 3. 
Table 3 Precompression Study of API and Formulated Blends

\begin{tabular}{|c|c|c|c|c|c|}
\hline $\begin{array}{c}\text { API and } \\
\text { formulation }\end{array}$ & $\begin{array}{c}\text { Bulk density } \\
\mathbf{g} / \mathbf{c m}^{\mathbf{3}}\end{array}$ & $\begin{array}{c}\text { Tapped density } \\
\mathbf{g} / \mathbf{c m}^{\mathbf{3}}\end{array}$ & $\begin{array}{c}\text { Compressibility } \\
\text { Index (\%) }\end{array}$ & $\begin{array}{c}\text { Hausner's } \\
\text { Ratio }\end{array}$ & $\begin{array}{c}\text { Angle of } \\
\text { Repose (Degree) }\end{array}$ \\
\hline Lansoprazole & $0.217 \pm 0.36$ & $0.383 \pm 0.02$ & $17.69 \pm 0.37$ & $1.20 \pm 0.24$ & $30^{\circ} 37^{\prime} \pm 0.54$ \\
\hline $\mathrm{N}-1$ & $0.224 \pm 0.03$ & $0.387 \pm 0.01$ & $21.89 \pm 0.26$ & $1.25 \pm 0.46$ & $3104^{\prime} \pm 0.72$ \\
\hline $\mathrm{N}-2$ & $0.223 \pm 0.06$ & $0.379 \pm 0.02$ & $21.74 \pm 0.83$ & $1.28 \pm 0.67$ & $30^{\circ} 36^{\prime} \pm 1.69$ \\
\hline $\mathrm{N}-3$ & $0.219 \pm 0.012$ & $0.386 \pm 0.03$ & $22.54 \pm 0.46$ & $1.29 \pm 0.92$ & $3233^{\prime} \pm 0.91$ \\
\hline
\end{tabular}

Mean \pm S.D $(n=3)$

The bulk density of the IR blends ranged from $0.217 \pm 0.36-$ $0.224 \pm 0.03 \mathrm{~g} / \mathrm{cm} 3$ and the tapped density ranged from $0.379 \pm 0.02-0.387 \pm 0.01 \mathrm{~g} / \mathrm{cm} 3$. The compressibility index of the IR blends ranged from $17.69 \pm 0.37 \%-22.54 \pm 0.46 \%$ and Hausner's ratio ranged from $1.20 \pm 0.24-1.29 \pm 0.92$. The angle of repose of the IR blends ranged from $3037^{\prime} \pm 0$. $54-3233^{\prime} \pm 0.91$. The formulated blends showed good flow property, so wet granulation technique was used for preparing IR granules of Lansoprazole.

The IR granules were evaluated for bulk density, tapped density, compressibility index, Hausner's ratio and Angle of repose. The results are given in Table 4.

Table 4 Precompression Study of Formulated IR Granules

\begin{tabular}{|c|c|c|c|c|c|}
\hline Formulation & $\begin{array}{c}\text { Bulk density } \\
\mathbf{g} / \mathbf{c m}^{\mathbf{3}}\end{array}$ & $\begin{array}{c}\text { Tapped density } \\
\mathbf{g} / \mathbf{c m}^{3}\end{array}$ & $\begin{array}{c}\text { Compressibility } \\
\text { index (\%) }\end{array}$ & $\begin{array}{c}\text { Hausner's } \\
\text { ratio }\end{array}$ & $\begin{array}{c}\text { Angle of } \\
\text { Repose (Degree) }\end{array}$ \\
\hline $\mathrm{N}-1$ & $0.213 \pm 0.26$ & $0.37 \pm 0.09$ & $23.27 \pm 0.88$ & $1.26 \pm 0.67$ & $3261^{\prime} \pm 0.39$ \\
\hline $\mathrm{N}-2$ & $0.213 \pm 0.32$ & $0.38 \pm 0.43$ & $24.83 \pm 0.78$ & $1.32 \pm 0.42$ & $3140 \pm 1.10$ \\
\hline $\mathrm{N}-3$ & $0.221 \pm 0.42$ & $0.35 \pm 0.09$ & $25.68 \pm 0.84$ & $1.28 \pm 0.63$ & $3164 \pm 0.13$ \\
\hline
\end{tabular}

Mean \pm S.D (n=3)

The bulk density of the IR granules ranged from $0.213 \pm 0$. $26-0.221 \pm 0.42 \mathrm{~g} / \mathrm{cm} 3$ and tapped density ranged from 0.35 $\pm 0.09-0.38 \pm 0.43 \mathrm{~g} / \mathrm{cm} 3$. The compressibility index of the IR granules ranged from $23.27 \pm 0.88 \%-25.68 \pm 0.84 \%$ and Hausner's ratio ranged from $1.26 \pm 0.67-1.32 \pm 0.42$. The angle of repose of the IR granules ranged from $3140 \pm 1$. 10$3261^{\prime} \pm 0.39$. The formulated IR granules showed good flow property.

\section{Preparation of IR tablets of Lansoprazole}

Wet granulation technique was employed for the formulation of IR granules of Lansoprazole. Three formulations of immediate release layer of Lansoprazole (N1, N2 and N3) were prepared using sodium starch glycolate (super disintegrant) in three different ratios. The granules were compressed using 10 station tablet compression machine using 10/32 punches. The result of Post Compession Study for Tablets was shown in table 5 .

Table 5 Post Compression Study of the Formulated Tablets

\begin{tabular}{|c|c|c|c|c|c|c|c|}
\hline Formulation & $\begin{array}{l}\text { Uniformity of } \\
\text { weight (mg) }\end{array}$ & $\begin{array}{l}\text { Diameter } \\
\text { (mm) }\end{array}$ & $\begin{array}{l}\text { Thickness } \\
\text { (mm) }\end{array}$ & $\begin{array}{c}\text { Hardness } \\
\left(\mathrm{kg} / \mathrm{cm}^{2}\right)\end{array}$ & \% Friability & $\mid \begin{array}{c}(\% \mathrm{w} / \mathrm{w}) \\
\text { Drug Content }\end{array}$ & $\begin{array}{l}\text { Disintegration } \\
\text { time (sec) }\end{array}$ \\
\hline Specified limit & $189.8-206.4$ & $4.5-5.0$ & $2.5-3$ & $3.5-4$ & $\begin{array}{c}\text { Not more than } \\
1.0 \%\end{array}$ & $90-110 \%$ & \\
\hline $\mathrm{N}-1$ & $197.21 \pm 0.35$ & $4.9 \pm 0.18$ & $2.6 \pm 0.49$ & $3.88 \pm 0.48$ & $0.67 \pm 0.12$ & $96.17 \pm 0.99$ & $42.02 \pm 0.79$ \\
\hline $\mathrm{N}-2$ & $196.14 \pm 0.78$ & $4.87 \pm 0.09$ & $2.62 \pm 0.19$ & $3.78 \pm 0.94$ & $0.72 \pm 0.02$ & $98.44 \pm 0.94$ & $29.05 \pm 0.90$ \\
\hline $\mathrm{N}-3$ & $199.38 \pm 0.91$ & $4.82 \pm 0.24$ & $2.68 \pm 0.03$ & $3.72 \pm 0.36$ & $0.70 \pm 0.12$ & $99.09 \pm 0.32$ & $24.07 \pm 0.92$ \\
\hline
\end{tabular}

Mean \pm S.D $(n=5)$

The tablets comply with the test for uniformity of weight, uniform in thickness and diameter have sufficient mechanical strength to resist the transportation. The percentage friability of all the formulations was within the acceptable limits. i.e not more than $1 \%$. The drug contents of all three IR formulations were found to be within the limit. i.e the drug content was not less than $90 \%$ and not more than $110 \%$ (as per IP: 2010). The disintegration time of the IR tablets ranged from 43.02 seconds to 19.07 seconds. The disintegration time of the IR tablets containing $8 \%$ sodium starch glycolate was found to have optimum disintegration time (19.07seconds) for IR tablets. 


\section{In Vitro Dissolution Study}

The in vitro dissolution of immediate release formulations of Lansoprazole is shown in table 6 and Fig 1.

Table 6 In Vitro Dissolution Study of Immediate Release Tablets

\begin{tabular}{|c|c|c|c|}
\hline \multirow{2}{*}{ Time(minutes) } & \multicolumn{3}{|c|}{ Cumulative \% Drug release } \\
\cline { 2 - 4 } & $\mathbf{N}-1$ & $\mathbf{N}-2$ & $\mathbf{N}-3$ \\
\hline 0 & $0 \pm 0.00$ & $0 \pm 0.00$ & $0 \pm 0.00$ \\
\hline 10 & $62.6 \pm 0.61$ & $80.42 \pm 0.16$ & $87.58 \pm 0.31$ \\
\hline 20 & $72.43 \pm 0.59$ & $87.43 \pm 0.61$ & $92.49 \pm 0.18$ \\
\hline 30 & $80.26 \pm 0.18$ & $94.63 \pm 0.41$ & $99.74 \pm 0.25$ \\
\hline 40 & $85.14 \pm 0.42$ & $97.87 \pm 0.41$ & \\
\hline 50 & $92.54 \pm 0.74$ & & \\
\hline 60 & $97.66 \pm 0.70$ & & \\
\hline
\end{tabular}

Mean \pm S.D $(n=3)$

The in vitro dissolution study of IR tablets showed that $8 \%$ concentration of SSG was found to be optimum for immediate release of Lansoprazole. The $4 \%$ and $6 \%$ concentration of SSG was found to be releasing the drug slowly when compared to $8 \%$ SSG. The $8 \%$ concentration of
SSG released $98.94 \%$ at the end of 30minutes. Therefore, formulation $\mathrm{N}-3$ was optimized and selected for final bilayer tablets. Formulation N-3 was optimized and selected for final bilayer tablets.

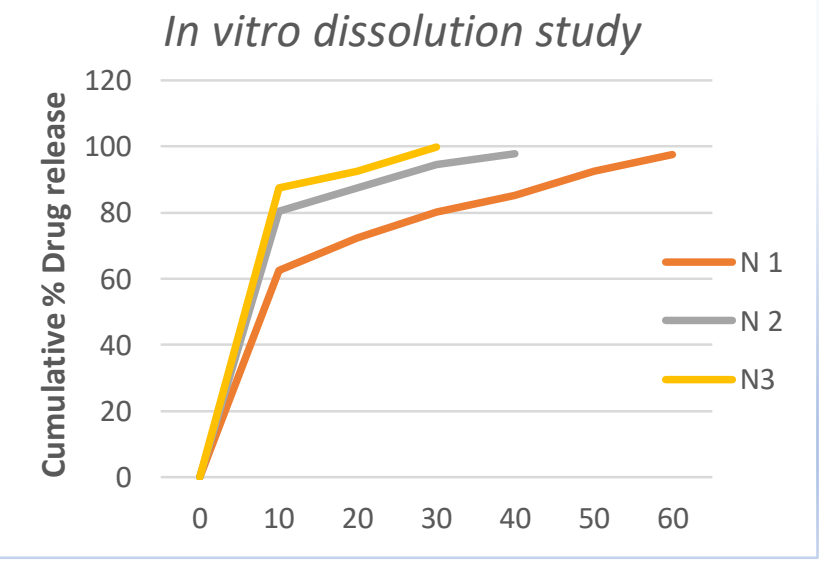

Figure 1 In vitro dissolution study of IR tablets of Lansoprazole

\section{Precompression Study for SR Tablets}

The API and the formulated blends of SR were evaluated for precompression parameters. The results are given in table 7.

Tablet 7 Precompression Study of API and Formulated Blends

\begin{tabular}{|c|c|c|c|c|c|}
\hline $\begin{array}{c}\text { API and } \\
\text { formulation }\end{array}$ & $\begin{array}{c}\text { Bulk density } \\
\mathbf{g} / \mathbf{c m}^{\mathbf{3}}\end{array}$ & $\begin{array}{c}\text { Tapped } \\
\text { Density } \mathbf{g} / \mathbf{c m}^{\mathbf{3}}\end{array}$ & $\begin{array}{c}\text { Compressibility } \\
\text { Index (\%) }\end{array}$ & $\begin{array}{c}\text { Hausner's } \\
\text { ratio }\end{array}$ & $\begin{array}{c}\text { Angle of } \\
\text { Repose (Degree) }\end{array}$ \\
\hline Amoxycillin & $0.26 \pm 0.03$ & $0.32 \pm 0.22$ & $26.36 \pm 1.35$ & $1.40 \pm 0.58$ & $29^{0} 66^{\prime} \pm 0.03$ \\
\hline NA-1 & $0.25 \pm 0.02$ & $0.33 \pm 0.82$ & $25.05 \pm 1.33$ & $1.44 \pm 0.80$ & $30^{0} 34^{\prime} \pm 0.90$ \\
\hline NA -2 & $0.27 \pm 0.02$ & $0.29 \pm 0.42$ & $17.02 \pm 0.69$ & $1.69 \pm 0.85$ & $31^{0} 40 \pm 1.10$ \\
\hline NA -3 & $0.27 \pm 0.03$ & $0.31 \pm 0.60$ & $17.82 \pm 0.01$ & $1.81 \pm 0.97$ & $31^{0} 58 \pm 1.64$ \\
\hline NA -4 & $0.27 \pm 0.06$ & $0.33 \pm 0.12$ & $18.70 \pm 0.14$ & $1.17 \pm 0.08$ & $32^{0} 40 \pm 0.66$ \\
\hline NA -5 & $0.26 \pm 0.03$ & $0.29 \pm 0.16$ & $18.82 \pm 0.99$ & $1.17 \pm 0.59$ & $31^{0} 83 \pm 0.64$ \\
\hline
\end{tabular}

Mean \pm S.D $(n=3)$ 
The bulk density of the SR blends ranged from $0.25 \pm 0.02-$ $0.27 \pm 0.06 \mathrm{~g} / \mathrm{cm}^{3}$ and the tapped density ranged from 0.29 $\pm 0.16-0.33 \pm 0.82 \mathrm{~g} / \mathrm{cm}^{3}$. The compressibility index ranged from $17.02 \pm 0.69 \%-26.36 \pm 1.35 \%$ and Hausner's ratio ranged from $1.17 \pm 0.08-1.69 \pm 0.85$. The angle of repose of the SR blend ranged from $29^{0} 66^{\prime} \pm 0.03-32^{0} 40 \pm 0.66$. The formulated blends showed good flow property so wet granulation technique was used for preparing SR granules of Amoxycillin. The SR granules were evaluated for bulk density, tapped density, compressibility index, Hausner's ratio and angle of repose. The results are given in table 8 .

Table 8 Precompression Study of Sustained Release Granules

\begin{tabular}{|c|c|c|c|c|c|}
\hline Formulation & $\begin{array}{c}\text { Bulk density } \\
\mathbf{g} / \mathbf{c m}^{3}\end{array}$ & $\begin{array}{c}\text { Tapped density } \\
\mathbf{g} / \mathbf{c m}^{\mathbf{3}}\end{array}$ & $\begin{array}{c}\text { Compressibility } \\
\text { Index (\%) }\end{array}$ & $\begin{array}{c}\text { Hausner's } \\
\text { ratio }\end{array}$ & $\begin{array}{c}\text { Angle of } \\
\text { Repose }\end{array}$ \\
\hline NA-1 & $0.27 \pm 0.06$ & $0.35 \pm 0.09$ & $22.27 \pm 1.88$ & $1.28 \pm 0.67$ & $3124 \pm 0.90$ \\
\hline NA -2 & $0.31 \pm 0.01$ & $0.38 \pm 0.43$ & $18.79 \pm 0.96$ & $1.23 \pm 0.45$ & $3121 \pm 0.39$ \\
\hline NA -3 & $0.25 \pm 0.05$ & $0.29 \pm 0.42$ & $15.02 \pm 0.61$ & $1.17 \pm 0.85$ & $3178^{\prime} \pm 0.53$ \\
\hline NA -4 & $0.26 \pm 0.13$ & $0.31 \pm 0.60$ & $15.82 \pm 0.69$ & $1.18 \pm 0.07$ & $3127 \pm 0.36$ \\
\hline NA -5 & $0.27 \pm 0.26$ & $0.33 \pm 0.82$ & $16.70 \pm 0.14$ & $1.20 \pm 0.08$ & $3123^{\prime} \pm 0.86$ \\
\hline
\end{tabular}

Mean \pm S.D $(n=3)$

The bulk density of the SR granules ranged from $0.25 \pm 0.05-$ $0.31 \pm 0.01 \mathrm{~g} / \mathrm{cm}^{3}$ and the tapped density ranged from 0.29 $\pm 0.42-0.38 \pm 0.43 \mathrm{~g} / \mathrm{cm}^{3}$. the compressibility index ranged from $15.02 \pm 0.61-22.27 \pm 1.88 \%$ and Hausner's ratio ranged from $1.17 \pm 0.85-1.28 \pm 0.67$. The angle of repose of the SR granules ranged from $3121 \pm 0.39-3178^{\prime} \pm 0.53$. The formulated SR granules showed good flow property.

\section{Formulation Development of SR Tablet}

Wet granulation technique was employed for the formulation of SR granules of Amoxycillin. Five batches of SR granules were prepared by using hydrophilic polymer HPMC $\mathrm{K} 100 \mathrm{M}$ and hydrophobic polymer EC in varying proportions. The formulations were compressed on a 10 station tablet compression machine and the result of post compression study shown in table 9 .

Table 9 Post Compression Study

\begin{tabular}{|c|c|c|c|c|c|c|}
\hline Formulation & $\begin{array}{l}\text { Uniformity of } \\
\text { weight (mg) }\end{array}$ & $\begin{array}{l}\text { Thickness } \\
\text { (mm) }\end{array}$ & $\begin{array}{c}\text { Diameter } \\
\text { (mm) }\end{array}$ & $\begin{array}{l}\text { Hardness } \\
\left(\mathrm{Kg} / \mathrm{cm}^{2}\right)\end{array}$ & Friability & $\begin{array}{c}\text { Drug content } \\
(\% \mathrm{w} / \mathrm{w})\end{array}$ \\
\hline Specified limit & 703-777 & $2.5-3.5$ & $4.5-5.5$ & $4-6$ & $\begin{array}{c}\text { Not more than } \\
1.0 \%\end{array}$ & $90-110 \%$ \\
\hline NA-1 & $751.32 \pm 0.79$ & $2.92 \pm 0.87$ & $4.8 \pm 0.49$ & $4.72 \pm 0.69$ & $0.79 \pm 0.26$ & $96.22 \pm 0.88$ \\
\hline NA - 2 & $761.38 \pm 0.53$ & $2.85 \pm 0.39$ & $4.72 \pm 0.69$ & $5.06 \pm 0.56$ & $0.82 \pm 0.00$ & $98.47 \pm 0.65$ \\
\hline NA -3 & $754.38 \pm 0.15$ & $2.86 \pm 0.48$ & $4.76 \pm 0.19$ & $5.12 \pm 0.15$ & $0.70 \pm 0.46$ & $97.52 \pm 0.95$ \\
\hline NA -4 & $754.00 \pm 0.93$ & $3.18 \pm 0.20$ & $4.74 \pm 0.16$ & $5.24 \pm 0.89$ & $0.91 \pm 0.27$ & $98.95 \pm 0.24$ \\
\hline NA -5 & $754.4 \pm 0.92$ & $3.12 \pm 0.66$ & $4.72 \pm 0.95$ & $5.18 \pm 0.94$ & $0.65 \pm 0.98$ & $99.30 \pm 0.23$ \\
\hline
\end{tabular}

Mean \pm S.D (n=5)

The tablet complies with the test for uniformity of weight, uniform in thickness, diameter and hardness. The percentage friability of all formulations was within the acceptable limits. i.e. not less than $1 \%$. The drug contents of all five SR formulations were found to be within the limit. i.e the drug content was not less than $90 \%$ and not more than 110\% (as per IP: 2010)

\section{In Vitro Dissolution Study of SR Tablets}

The in vitro dissolution study of SR tablets is given in table 10 and Fig 2. 
Table 10 In Vitro Dissolution Study of SR Tablets

\begin{tabular}{|c|c|c|c|c|c|}
\hline $\begin{array}{c}\text { Time } \\
\text { (minutes) }\end{array}$ & NA-1 & NA-2 & NA-3 & NA-4 & NA-5 \\
\hline 0 & $0 \pm 0.00$ & $0 \pm 0.00$ & $0 \pm 0.00$ & $0 \pm 0.00$ & $0 \pm 0.00$ \\
\hline 30 & $42.38 \pm 0.56$ & $41.47 \pm 0.55$ & $36.34 \pm 0.94$ & $26.42 \pm 0.70$ & $23.97 \pm 0.42$ \\
\hline 60 & $50.55 \pm 0.48$ & $46.57 \pm 0.58$ & $41.50 \pm 0.11$ & $32.59 \pm 0.72$ & $27.37 \pm 0.69$ \\
\hline 120 & $58.22 \pm 0.32$ & $55.56 \pm 0.15$ & $46.28 \pm 0.83$ & $39.44 \pm 0.68$ & $33.59 \pm 0.53$ \\
\hline 180 & $67.05 \pm 0.13$ & $65.53 \pm 0.33$ & $52.28 \pm 0.18$ & $45.36 \pm 0.40$ & $39.45 \pm 0.72$ \\
\hline 240 & $72.56 \pm 0.87$ & $71.50 \pm 0.97$ & $59.38 \pm 0.89$ & $50.45 \pm 0.32$ & $47.84 \pm 0.50$ \\
\hline 300 & $81.24 \pm 0.75$ & $79.31 \pm 0.24$ & $68.37 \pm 0.51$ & $56.28 \pm 0.84$ & $54.10 \pm 1.40$ \\
\hline 360 & $92.25 \pm 0.21$ & $84.58 \pm 0.30$ & $77.45 \pm 0.53$ & $62.45 \pm 0.72$ & $59.57 \pm 0.60$ \\
\hline 420 & $96.39 \pm 0.91$ & $90.64 \pm 0.51$ & $83.28 \pm 0.87$ & $67.25 \pm 0.54$ & $67.53 \pm 1.14$ \\
\hline 480 & $98.42 \pm 0.90$ & $97.49 \pm 0.82$ & $88.78 \pm 0.22$ & $73.28 \pm 0.93$ & $68.40 \pm 0.56$ \\
\hline 540 & & $99.51 \pm 0.46$ & $93.35 \pm 0.94$ & $79.26 \pm 0.34$ & $77.54 \pm 0.34$ \\
\hline 600 & & & $99.23 \pm 0.25$ & $87.92 \pm 0.23$ & $84.78 \pm 0.59$ \\
\hline 660 & & & & $99.73 \pm 0.83$ & $92.34 \pm 0.85$ \\
\hline 720 & & & & & $99.82 \pm 0.95$ \\
\hline
\end{tabular}

Mean \pm S.D $(n=3)$

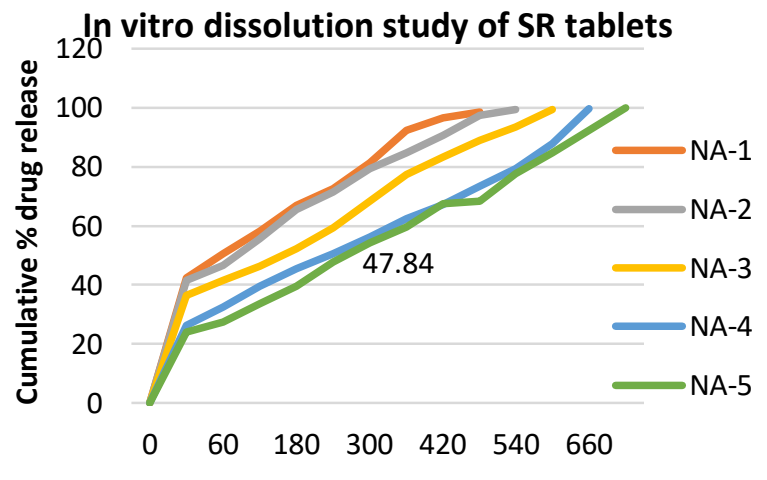

Figure 2 In vitro dissolution study of SR tablets

Based on the comparative release profile, formulation NA-5 was selected for the final bilayer tablets.

\section{Formulation Development Preparation of Bilayer Tablets}

Optimized immediate layer of Lansoprazole was prepared by wet granulation method. Optimized sustained release layer of Amoxycillin was prepared by wet granulation method. The granules were compressed on 10 station bilayer tablet compression machines and result were shown in table 11.

Table 11 Post Compression Study of Bilayer Tablets

\begin{tabular}{|c|c|}
\hline Parameters & Bilayer tablet \\
\hline Uniformity of weight (mg) & $824.18 \pm 0.63$ \\
\hline Thickness (mm) & $5.21 \pm 0.07$ \\
\hline Diameter (mm) & $4.71 \pm 0.15$ \\
\hline Hardness $\left(\mathrm{kg} / \mathrm{cm}^{2}\right)$ & $5.02 \pm 0.28$ \\
\hline Friability (\%) & $0.37 \pm 0.13$ \\
\hline $\begin{array}{c}\text { Drug content* } \\
\text { (simultaneous estimation method) }\end{array}$ & \\
\hline 1. Lansoprazole & $1.97 .46 \pm 0.15$ \\
\hline 2. Amoxycillin & $2.98 .25 \pm 0.14$ \\
\hline
\end{tabular}

In Vitro Dissolution Study of Lansoprazole in Bilayer Tablet

The in vitro dissolution study of drugs in bilayer tablets is given in table 6.12 and Fig 3

Table 12: The in vitro dissolution study of Lansoprazole in bilayer tablet

\begin{tabular}{|c|c|}
\hline Time (minutes) & \% Drug release \\
\hline 0 & $0 \pm 0.00$ \\
\hline 10 & $78.27 \pm 0.26$ \\
\hline 20 & $92.24 \pm 0.12$ \\
\hline 30 & $97.46 \pm 0.15$ \\
\hline \multicolumn{2}{|c|}{ Mean \pm S.D (n=3) }
\end{tabular}

The in vitro dissolution study of Lansoprazole in bilayer tablet

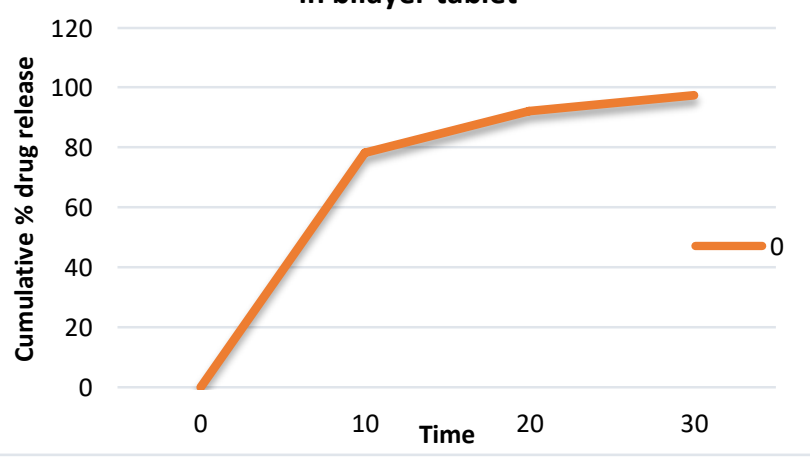

Figure 3 The in vitro dissolution study of Lansoprazole in bilayer tablet 
Table 13: In Vitro Dissolution Study Of Amoxycillin In Bilayer Tablet

\begin{tabular}{|c|c|}
\hline Time (minutes) & \% Drug release \\
\hline 0 & $0 \pm 0.00$ \\
\hline 30 & $27.14 \pm 0.91$ \\
\hline 60 & $33.21 \pm 0.14$ \\
\hline 120 & $38.24 \pm 0.25$ \\
\hline 180 & $46.27 \pm 0.15$ \\
\hline 240 & $55.66 \pm 0.48$ \\
\hline 300 & $60.15 \pm 0.69$ \\
\hline 360 & $67.71 \pm 0.07$ \\
\hline 420 & $72.16 \pm 0.43$ \\
\hline 480 & $79.47 \pm 0.31$ \\
\hline 540 & $85.15 \pm 0.65$ \\
\hline 600 & $91.17 \pm 0.41$ \\
\hline 660 & $98.25 \pm 0.14$ \\
\hline 720 & \\
\hline
\end{tabular}

Mean \pm S.D (n=3)

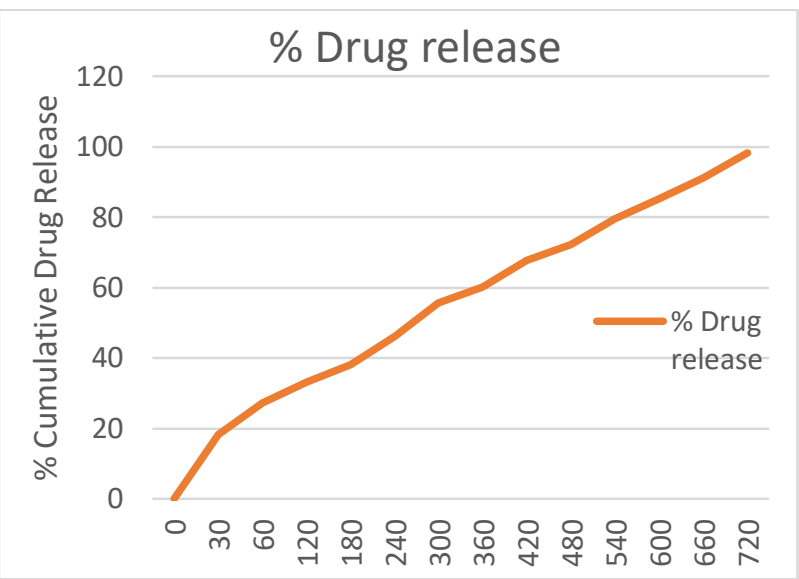

Figure 4 In vitro dissolution study of Amoxycillin in bilayer tablet

\section{CONCLUSION}

Lansoprazole potentiate the effect of Amoxycillin. Hence the bilayer tablets of Lansoprazole and Amoxycillin were used to improve patient compliance towards the effective management of ulcer. Thus, from the result, it can be concluded that the bilayer tablets containing $15 \mathrm{mg}$ of Lansoprazole as immediate release component and $500 \mathrm{mg}$ amoxycillin as sustained release component has successfully developed. The results of current study clearly show that bilayer tablet was developed as a stable dosage form.
Lansoprazole and amoxycillin bilayer tablet have a promising potential as an alternative to the conventional dosage form. This new dosage form has commercial marketing potency as no such delivery systems are presently available in market.

\section{ACKNOWLEDGMENT}

We are thankful to Dr. Surendra Kumar Jain, Director, Sagar Institute of research \& Technology Pharmacy, Bhopal India for providing work space. We are very much grateful to Sri Pharmacare Powai, Mumbai, India for providing the gift samples of drug, Lansoprazole and Amoxycillin.

\section{REFERENCES}

1. Matheson AJ, Jarvis B. Lansoprazole. Drugs. 2001; 61(12):180133.

2. Bown RL. An overview of the pharmacology, efficacy, safety and cost-effectiveness of lansoprazole. International journal of clinical practice. 2002; 56(2):132-9.

3. Nakao M, Malfertheiner P. Growth inhibitory and bactericidal activities of lansoprazole compared with those of omeprazole and pantoprazole against Helicobacter pylori. Helicobacter. 1998; 3(1):21-7.

4. Korolkovas, A. Essentials of Medicinal Chemistry, $2^{\text {nd }}$ ed., New York: Wiley-Interscience. 1988; 1216.

5. Devani MB, Patel IT, Patel TM. Spectrophotometric determination of amoxycillin and its dosage forms. Journal of pharmaceutical and biomedical analysis. 1992; 10(5):355-8.

6. Bird AE. Amoxicillin. InAnalytical profiles of drug substances and excipients 1994; 23: 1-52.

7. Carceles CM, Escudero E, Vicente MS, Serrano JM, Carli S. Pharmacokinetics of amoxicillin/clavulanic acid combination after intravenous and oral administration in goats. Veterinary Quarterly. 1995; 17(4):134-8.

8. Pasqualoto KF, Funck JA, Silva FE, Kratz C. Development and Evaluation of Amoxicillin Formulations by Direct Compression: Influence of the Adjuvants on Physicomechanical and Biopharmaceutical Properties of the Tablets. Acta Farmaceutica Bonaerense. 2005; 24(1):39-47

9. Westphal JF, Deslandes A, Brogard JM, Carbon C. Reappraisal of amoxycillin absorption kinetics. Journal of antimicrobial chemotherapy. 1991; 27(5):647-54.

10. Kumar AH, Kavitha K, Kumar SA, Kumar MR, Singh SD. Novel Approach of bilayer tablet technology-a review. International journal of pharmaceutical, Chemical \& Biological Sciences. 2013; 3(3):887- 893

11. Lopes CM, Lobo JM, Pinto JF, Costa PC. Compressed matrix core tablet as a quick/slow dual-component delivery system containing ibuprofen. Aaps Pharmscitech. 2007; 8(3):195-202.

12. Maggi L, Machiste EO, Torre ML, Conte U. Formulation of biphasic release tablets containing slightly soluble drugs. European journal of pharmaceutics and biopharmaceutics. 1999; 48(1):37-42.

13. Lieberman HA, Lachman L, Schwarz JB. Pharmaceutical dosage forms: Tablets. New York and Basel.: Marcel Dekker, 1989, 2:154.

14. Beckett AH, Stenlake JB. Practical Pharmaceutical Chemistry, part-II. CBS Publications and Distributors, New Delhi. 1997; $1: 275-320$.

15. Vinod KR, Sri AP, Banji D, Anbazhagan S, Vasa S, Sandhya S. Formulation and in vitro characterization of lansoprazole floating gastroretentive microspheres by modified non aqueous solvent evaporation method. Der Pharma Chemica. 2010; 2(5):500-6. 